\title{
The Relationship between Teacher Management Style in and out the Class, and Student Performance in the Faculty of Business at the Lebanese University
}

\author{
Dr. Antoine Tannous*
}

Faculty of Economics and Business Administration, Lebanese University - Branch III, Dahr El Ain, Lebanon

DOI: $\underline{10.36347 / \text { sjebm.2020.v07i03.001 }}$

| Received: 28.02.2020 | Accepted: 09.03.2020 | Published: 13.03.2020

*Corresponding author: Antoine Tannous

Abstract

Original Research Article

The management style of teaching is important to improve student performance. There are many teaching management style. The important is to find the best one that fit the students' situations. And to go beyond the chapter explanation and to let the students understand and to be more implicated. The final teachers' objectives are to help and illuminate the road to the student building and succeeding his future. Our research focuses on one qualitative study and two quantitative studies. The qualitative study, address to the professional masters' teachers in order to improve their choices of teaching styles. The main results show a traditional management style, between democratic and need for training to improve their information how to behave properly when they manage the class. The first quantitative study, shows that the management styles used by teachers are in general authoritarian. The second quantitative study to the students confirm that teachers management styles don't fit sometime the need of students in order to understand, to motivate them and push them further in their future career.

Keywords: Teaching style, teaching management, management style of teaching, student performance.

Copyright @ 2020: This is an open-access article distributed under the terms of the Creative Commons Attribution license which permits unrestricted use, distribution, and reproduction in any medium for non-commercial use (NonCommercial, or CC-BY-NC) provided the original author and source are credited.

\section{INTRODUCTION}

The classroom management styles get an importance as the research indicates. They let students to have good achievement. Also, this helps them to have successful future. So, that why teacher management style in the classroom is important to evaluate and to advice in order to improve.

The purpose of this research is: To know the better teaching management style; to identify the actual teaching style and its gaps; to find factors that allows best teaching style; and to find factors that allow to increases students performance.

Our research questions are: What are the current teaching management styles? Where are the gaps in the current teaching management styles? What are the innovations in teaching management styles? What are students' performances? Which teaching management styles draw the students' attention in classes in order to let them increase their performance? And what teaching management styles draw the students' attention out the classes in order to let them increase their performance?

\section{Our Hypotheses are:}

$\mathrm{H} 1$ : Teacher management style in class, draw student attention.

$\mathrm{H} 2$ : Teacher management style out the class, draw student attention.

H3: Teacher management style in class let the student to take notes and participate.

H4: Teacher management style out the class draw student to take notes and participate.

H5: Teacher management style in class allow student to understand better the explanations.

H6: Teacher management style out the class, allow student to understand better the explanations.

H7: Teacher management style in class motive student to study.

H8: Teacher management style out the class motive student to study.

H9: Teacher management style in class will let the students cooperate between them in order to succeed.

H10: Teacher management style out the class motive student to study and to let the students cooperate between them in order to succeed.

H11: Teacher management style in class will help student to succeed in his career. 
H12: Teacher management style out the class will help student to succeed in his career.

\section{Teacher Management Style}

According to Bass, 1985 [1]; Bass and Avolio, 1989 [2]; Hater and Bass, 1988 [3]; Den Hartog et al., 1997 [4]; Hinkin and Tracey, 1999 [5]; we will present the different teacher management style:

\section{Authoritarian}

The authoritarian teacher imposes firm limits and controls on students. Students must be in their places at the start of the course and they stay there frequently throughout the period. This teacher rarely gives passes or acknowledges excused absences.

Students know that they must not interrupt the teacher. And this leads to a lack of learning and communication on the part of the students. This teacher prefers strict discipline and quick obedience.

The authoritarian teacher does not take care of motivating these students. His students rarely receive encouragement, and often none. In addition, he makes no effort to organize practical activities complementary to the course he teaches theoretically.

These activities can be case studies and field trips. He believes that these additional activities only distract students from learning. After all, the authoritarian teacher thinks that students only have to listen to his lecture to acquire the necessary knowledge. Thus, the students do not dare to propose activities. Because the teacher imposes everything in class without taking the students' opinion if this suits them. Therefore, his style does not motivate students or encourage them to set personal goals to improve in their studies.

\section{Authoritative}

The authoritative teacher imposes limits and controls students but simultaneously promotes independence. He often explains the reasons for these rules and decisions. If the student is disruptive, he imposes a polite but firm warning on him. This teacher sometimes imposes discipline, but after having checked the causes of disturbance.

The authoritative teacher accepts verbal interaction, including critical debate. Students know that they can interrupt the teacher if there is an important question or comment. This environment encourages students to learn and practice communication skills, because the teacher has a warm and encouraging behavior towards these students. Also, his explanations are based on practice to explain the theory and this allow these students to better understand. These students feel encouraged and at ease with him.

\section{Democratic}

The democratic teacher demands little control over his students. He uses a democratic style. He avoids saying no and hurting the feelings of his students at the expense of discipline. The rules are not sufficiently applied in class. He seeks to be the friend of the students. He allows them to interrupt him because he considers that it is for something important.

Students like the behavior of this teacher and prefer him to others. However, this lenient behavior causes disorder in the classroom and lowers student motivation. In consequences, this causes students to reach a lower level of study.

\section{Laissez-Faire}

The "laissez-faire" teacher imposes few rules in the classroom and is not very involved in the classroom. He does not prepare his lessons and often they are the same as last year. He does not update them. $\mathrm{He}$ teaches a quarter of an hour to thirty minutes maximum. The motivation of the students is very weak, they are left to their own fate and do not have the opportunity to improve their communication skills and know with this teacher.

\section{The Transformational Leadership}

The transformational teacher motivates influence, supervise and help the student to improve his current state. He stimulates students and detects their needs in order to motivate and inspire them. He is admired and respected by his students. He always updates his knowledge. He encourages students to communicate and to make practice on the theory.

\section{The Current Teaching Management Styles}

Okoroji et al., [6] examined the effect of leadership styles on teaching and learning process. The results of their study show that majority of teachers use democratic style in managing their class room. Interaction is important between teacher and students, in order to let them to better understand. So teaching style is important to allow students to succeed in classes.

This is reflected in the teacher-student relationship in the teaching and learning process, which is consistent that the democratic leadership style encourages class participation in decision-making. The student seems to be satisfied with what gives them a sense of belonging and value as a person who could contribute to the success of the class.

Also, the study reveals that gender influence to high extent the leadership style used in classroom. This is consistent with the findings of Eagly, Johnson [7] and Rosener [8] and other researchers who found mean style as directive, autocratic and transactional and described the feminine style as participative or democratic, which naturally comes to them more often than men. 
As well, Okoroji et al., [6] advise to adapt teaching method according to class situation and to have continual training to support teacher to improve his teaching method.

To complete this reasoning, a thesis done by James stuart Pounder [9] show that university professors' use of the active transactional and transformational dimensions. This classroom leadership style was significantly and positively associated with students' outcomes. In this study, no gender effect was detected. In addition, there was an indication that the adoption of the transactional and transformational style in the classroom could have a substantial positive effect on the student's assessment of teaching outcomes, although this conclusion is inconclusive because of the limited sample size. Finally, the results reinforced the view that the notion of transformational-transactional leadership is strong across all cultures. Although, while the transactional leader may motivate subordinates to behave as expected, the transformational leader has the ability to attract subordinates to performance levels that exceed expectations [4].

\section{Transformational-Transactional Leadership and the University}

Research by Ojode and colleagues [10] and Walumbwa and Ojode [11] suggest that there is insufficient research on the effects of transformationaltransactional leadership in the classroom. However, research results in the field of leadership on the transformational-transactional concept show the importance of new experiences on transformationaltransactional leadership in university class, in particular given the relevance of these results in leadership for improvement of educational performances. After all, in addition to the potential beneficial effect on student evaluation of teaching outcomes, most university professors hoped to intellectually stimulate students, generate effort in the subject and helping students to be satisfied with the content and the teaching process. Studies respond to the needs of their students and teachers to produce effective results. That the relevance of transformational-transactional leadership for a university classroom is largely important and necessary for good quality academic training resulting from indepth work on the teaching process and thus producing excellent academic results.

\section{Effective Management Style and Student Performance}

Moving from inappropriate to appropriate behavior Researchers, including Maeroff [12], talk about poverty and in its effects. They explain that poor students often are deficient in social capital like, lack of good study habits and discipline. And they don't have the opportunities to practice activities that increase their knowledge. Like traveling, summer camp, home computers, music, arts and sports lessons...
So, because these students lack of belonging to community, neighborhood or school, they don't have adults to advice them and to help them to face problems in their life, in and out the school. As a results, hope for them is difficult to attain. And as a consequence they have a low level of confidence and self respect.

To find solutions for these problems described before, several measures should be taken. Between them, we have to make a classroom arrangement in order to draw student attention.

Classroom management expert Fred Jones says teacher mobility should be the aim of any classroom seating arrangement. This arrangement is among several different seating configurations illustrated in Jones's book, Tools for Teaching.

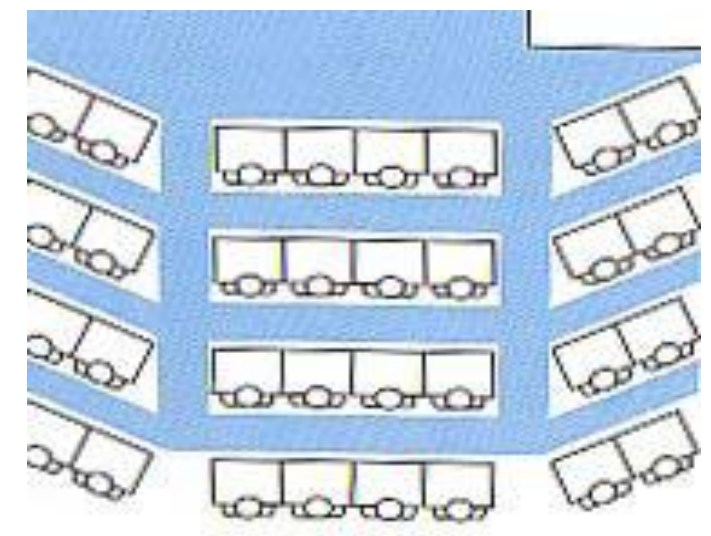

Fig-1: A good classroom seating arrangement is the cheapest form of classroom management [13]

Research on classroom management has focused on student participation in establishing codes of conduct to solve students' inappropriate behavior, rather than using punishment. Because students could behave inappropriately because of many reason like their parents fought all night and they didn't sleep well...that why teacher should be tolerant and try to find the problem and how to draw their attention.

We have so far focused our attention on understand students' behavior on the part of students evaluation of inappropriate improvement strategies behavior. However, an equally important subject regards the management style of the teacher. It is, how much do you know about your teacher style? And your aptitude to interact with students? Are you authoritarian in your approach to teaching, more than one authoritative teacher, or you don't care like laissez-faire style of teacher? So, understanding your profile increases your ability to correct inappropriate behavior before it degenerates into something more serious. Knowledge your limits (that is, your tolerance level of certain behaviors) and your students facilitate your potentially problematic de- escalation ability situations. 
Otherwise, these are some advices how to deal with students: know your student; never publicly humiliate him. Try to adapt your voice, for example at the end of the day don't speech loudly. Tell student some time something about you to let them feel you are human too. Exchange your experience with other teacher in order to learn from them new ideas how to deal with students. Allow your student to feel that they are building competence each time you teach them. And always teacher should have a positive thought.

So we can be concluded that the management style of the class of teachers is a very important factor for the effectiveness of teaching, especially with regard to student achievement. As we conclude above that the researches confirm the advantages of the interactionist style in classroom management compared to interventionist and non-interventionist styles. A teacher who practices an interactionist style encourages interaction and cooperation in the classroom, respects the student's personality, values his / her initiatives, interests and needs. He uses teaching methods and materials that allow the entire class to benefit from all classroom activities and well-targeted learning objectives, puts in place procedures to establish selfdiscipline - control and accountability of students. In short, the teacher "interactionist" shares the responsibility for the classroom situation with the students. This helps to create a social climate that stimulates the learning and personal growth of its students. Because of the positive social climate and active participation of students in the teaching and learning process, the classroom becomes a stimulating and safe learning environment. Therefore, such a teacher is able to achieve the best results in the educational process. Also a master thesis directed by Sandra Durodola [14]. Explain in her thesis that democratic style suite the most for under-resourced classroom conditions, like in the Lebanese university. But some time they use autocratic management style to make discipline.

In addition a study was conducted by Brown and Akwesi Owusu [15], show that the administration of high schools in Ghana faces many problems, most of which stem from shortcomings in the management styles of those in charge of these institutions. Teachers have sometimes held open demonstrations to show their dissatisfaction with the management styles of school leaders, which they often describe as administrative and managerial incompetence. The study, among other things, revealed that most teachers see their head as a leader and not as a friend. Again, it was revealed that although the teachers were involved in the decisionmaking process, the definition of a school's objectives was assigned to the school's leaders and management team. And there were no objectives to follow by teachers. It was therefore recommended that school principals adopt the walking management style and
Management by Objective principles in order to be closer to their teachers in school management.

\section{Teacher Management Style and Stress}

In accordance with R. Parveen et al., [16], one of the main causes that contribute to teachers' stress is how to deal with problematic student behaviors in a university classroom. However, coping strategies may mitigate the effects of classroom management styles on teachers stress levels. The study focused on the relationship between classroom management style and coping strategies with stress.

Research findings indicated a significant negative relationship between authoritarian management style and teacher stress. Research also shows a significant positive relationship between authoritative and democratic management style and stress among teachers. In addition, the results of this study show a non-significant positive relationship between laissez-faire management style and teacher stress, while a significant negative relationship between a brief coping strategy and teacher stress.

This study shows the relationship between class management styles, coping strategies and stress. The study showed that if coping strategies are effective, they cause low stress for teachers. We mean that if coping strategies work well, the teacher has a low level of stress. The authoritarian and authoritative style of classroom management will also play an important role in overcoming teacher stress. There is no doubt that teaching is a difficult task, a workload and a source of stress exhaustion, but good management skills help to cope with the different stressful situations of teachers. "

\section{How do students learn?}

Teaching content is not enough for a teacher. He has to take into consideration that students came from different culture and they have different perception. So, he has to adapt or to modulate his teaching way to be appropriate to each student background and culture. Teaching adaptation is important to help students' difficulties. Because of that it is also important to let each teacher to define learning objectives and the knowledge and skills that we expect from the student at the end of the course. Also teacher has to let students practice theories learned in the courses by doing case studies, labs, readings, discussions and then assessment. In this way teaching is more effective and student knowledge will increase (Figure-2). 


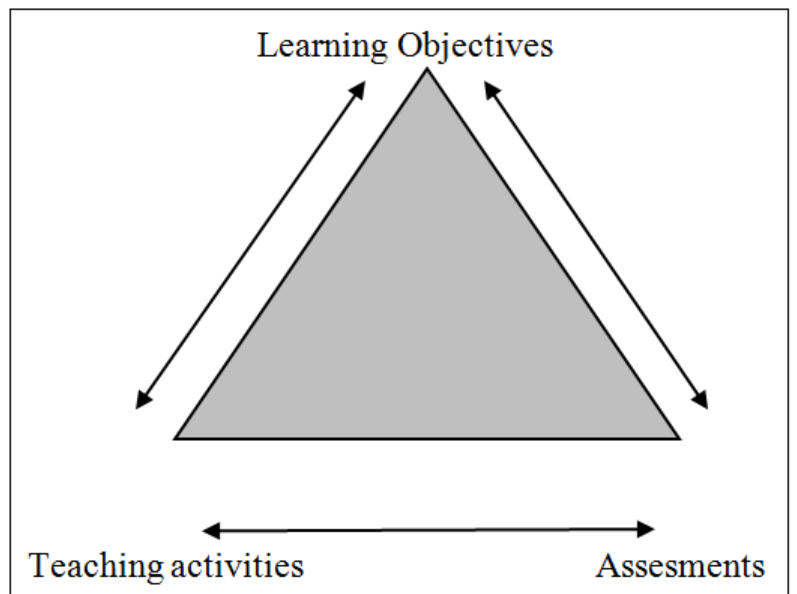

Fig-2: Aligning the three major components of instruction

Student expectations vary greatly from one classroom to another and even within a given discipline. For example, what constitutes proof may vary considerably from one course to another; what is allowed collaboration in one course is not being able in another. As a result, student expectations may not match ours. As a result, the clarity of our expectations and their explicit communication help students learn more and achieve better performance. Similarly, being explicit about course policies (for example, about class participation, laptop use, and late attribution) in the curriculum and in the classroom allows us to reduce conflicts and tensions that may arise.

On the other hand, each student has his teaching and learning styles. Some of them are visual, others are auditory and others are kinesthetic. Visual student is someone who emphasis on seeing, watching, viewing and drawing. Another are auditory they stress on listening and speaking. And others are kinesthelic. They emphasis on doing, demonstrating, showing and direct involvement. A wise teacher should take into consideration the three styles as shown in Figure-3.

\begin{tabular}{|c|c|c|}
\hline $\begin{array}{l}\text { Learner's } \\
\text { Modality }\end{array}$ & Teacher Should ... & Learner Should ... \\
\hline Visual & $\begin{array}{l}\text { - Write on the board or an overhead. } \\
\text { - Use chart paper. } \\
\text { - Use videos, slides, and other visual } \\
\text { material. } \\
\text { - Look at students while talking. } \\
\text { - Encourage note taking. } \\
\text { - Use color. } \\
\text { - Preview chapters by showing pictures, } \\
\text { bold-faced print, etc. } \\
\text { - Use demonstrations. } \\
\text { - Provide a quiet environment in which } \\
\text { students can work alone. }\end{array}$ & $\begin{array}{l}\text { - Write things down. } \\
\text { - Look at people when they talk. } \\
\text { - Study alone in a quiet place. } \\
\text { - Take lots of notes. } \\
\text { - Re-copy class notes. } \\
\text { - Use color to highlight main ideas. } \\
\text { - Preview a chapter by looking at it first. } \\
\text { - Sit near the front of the class. } \\
\text { - Write vocabulary words in color on } \\
\text { cards. } \\
\text { - Use lined paper. } \\
\text { - Visualize or use pictures to reinforce } \\
\text { vocabulary and concepts. }\end{array}$ \\
\hline Auditory & $\begin{array}{l}\text { - Give verbal directions. } \\
\text { - Talk students through a task or } \\
\text { process. } \\
\text { - Test verbally. } \\
\text { - Allow students to talk about subjects. } \\
\text { - Encourage/ study groups. } \\
\text { - Read to students. } \\
\text { - Use cassettes and encourage students } \\
\text { to use them, too. } \\
\text { - Use music as a background when } \\
\text { appropriate. } \\
\text { - Preview a book by talking about what } \\
\text { it will cover. }\end{array}$ & $\begin{array}{l}\text { - Study with a partner or in groups. } \\
\text { - Recite information. } \\
\text { - Tape lectures and listen to them. } \\
\text { - Read aloud. } \\
\text { - Have music in the background. } \\
\text { - Tape yourself explaining concepts. } \\
\text { - Preview a book by saying out loud } \\
\text { what you think it will cover. }\end{array}$ \\
\hline Kinesthetic & $\begin{array}{l}\text { - Let students manipulate materials } \\
\text { before theories are explained. } \\
\text { - Allow break time. } \\
\text { - Allow students to write on the board. } \\
\text { - Allow movement. } \\
\text { - Use role-play and dramatization. } \\
\text { - Encourage note taking. } \\
\text { - Do "labs." } \\
\text { - Go on field trips. }\end{array}$ & $\begin{array}{l}\text { - Take breaks. } \\
\text { - Move/pace when learning. } \\
\text { - Use role-play as a learning tool. } \\
\text { - Try studying stretched out rather than } \\
\text { sitting in a chair. } \\
\text { - Use a bright piece of paper in a favorite } \\
\text { color as a desk blotter for color } \\
\text { grounding. } \\
\text { - Try "tracing" difficult information (in } \\
\text { the air, on paper, etc.) } \\
\text { - Try reading while pedaling a stationary } \\
\text { bike. } \\
\text { - Take notes. }\end{array}$ \\
\hline
\end{tabular}

Fig-3: Perceptual modalities - learning styles [17] 


\section{Teachers competences and students performances}

Teacher competence is related to student performance [18]. A competent teacher can be a good source of positive results for students. He is able to handle the complex situation of his students. On this basis, Emmer [19] demonstrated that a successful teacher is not only effective in the knowledge passed on to students, but also effective in his classroom situations. He or she should know how to manage the class for effective student learning, master the skills, and describe how to apply skills and knowledge effectively.

If the teacher's learning style is relaxed and new very will how to transmit his knowledge, his level of enthusiasm is high, he offers a warm classroom atmosphere that encourages students to perform well and accept the new challenges of reflection proposed by his teachers.

In the same way, Elliot et al., [20] pointed out that effective teaching requires an interesting teaching environment and teaching technique. Hsu [21] found similar results. Teachers who succeed in creating a climate of warmth and support can extract the best results from students.

In addition, Muzenda [22] examines the influence of different dimensions of a teacher's competence. Specifically the lecturer's pedagogical skills, his knowledge of the subject, his attitude and diligence. The study found that these factors had a significant positive influence on students' academic performance. He found strong positive correlations between teacher competence and student academic achievement. In this regard, it can be inferred that providing teachers with training on the specified components of the lecturer's competence can effectively improve the quality of the teaching taught in order to achieve high academic performance.

For its part, Partono Prasetio et al., [23] suggests that the lecturer's professional skills can not lead the student to achieve better academic results. Other factors contribute more to this performance. These factors include educational facilities, student motivation, economic background, family history, role of parents, previous studies, and peer influence. This list can continue to grow as many factors can influence students (technology, social). Nevertheless, the lecturer must always develop his professional skills. Speaker considered an important part of the learning process. Their knowledge and positive behavior will certainly add new ideas and experiences to the student. Although they can not affect student performance, they can at least help them prepare for life after graduation.

\section{Innovation in Teacher Management Style}

We have to encourage the student and teacher continual learning and to use the on-line learning. In order to allow students and teachers to have lifelong education [24].

Lifelong education requires the all-round development of all citizens, and this in turn requires a new series of teaching contents and forms. In view of this requirement, the meaning of lifelong education is not limited to education only; it also encompasses a new communication mode in society. We should be attentive to this new communication mode; education should be the major communication mode between people - and between people and society. Regarding today's social development, the social communication mode should be mainly education-related rather than benefit-related. From the perspective of education and educational relationships, ethics, law and cultural ideologies, and the development of the whole society including the production process should bear a new form, so that the new social system and social structure can be established. Lifelong education will then become a high-level education spectrum with enrichment in terms of ideology, policy, and innovation.

The ideology of lifelong education will become an important ideology of education philosophy, education economics, and education sociology. Lifelong education law and policy should become the leading contents of education law and policy. Lifelong education organizations will then become learning organizations; lifelong education societies become learning societies; and the ideology of lifelong education becomes life philosophy and social philosophy. Everybody will find himself or herself presented as a new person in the ethical horizon of lifelong education and lifelong learning; be able to acquire new knowledge; earn new friendship and love; and ultimately enjoy a prosperous life.

According to an article on how to review and strengthen the education system in Ireland [25], the experience of locating and reusing open educational resources in the construction of comprehensive higher education courses has been a definite success. The two proposed research areas are:

Skills required by academics to locate, identify, and recombine open curriculum resources in their course materials and learners' experience in using these hybrid course resources (Open Learning Resources + Contextual Original Materials) for their own study. In particular, to what extent are they tempted to continue to explore trustworthy sources identified for their own self-motivated study activities? 
In addition, according to Cowan [26], he describes the key strategies used to develop and maintain a successful hybrid community of practice.

Between 2000 and 2009, 243 students from 11 cohorts participated in a program on Internet-based education technology. It is a hybrid master's program in education focused on educational technologies. Students in the program work collaboratively in a problem-based approach to integrating technology into teaching.

Program completion rates are higher than those of other online programs and even higher than traditional face-to-face master's programs.

In addition, graduates of the program become leaders in educational technology. Using a community of practice model for its participants is one of the keys to the program's success.

An analysis of 78 course reflections and 92 post-program surveys revealed that the communitybuilding strategies used in the program helped to improve the student experience and increase program completion rates.

In other hand, organizational and communication requirements this approach can be more difficult for the online teacher, who must support students to use technology appropriately and effectively [27]. Example:

- More time is needed to prepare the resources that students can use at their own pace. The resources should capture some of the information that orientation teachers would provide verbally in faceto-face discussions. In order to know the suitable way to use in communicating with students (whatsup, email, facebook...).

- Communicating with students online can be extremely demanding, as interactions are spread throughout the week rather than mainly during university hours or in consultation.

To enters on-line teaching and teaching campuses that can be applied to a wide range of teaching situations. These can be summarized as follows:

- An online fashion movement has expanded the range and scope of teaching responsibilities. Online education not only do we need to find new ways to facilitate learning, but we also need to implement new activities that are not part of the on-campus teaching and changing work patterns associated with increased preparation in advance of the teaching session. This requires the development of technical skills and practical strategies.

- Technology dependency affects all aspects of elearning, while it is in campus mode technology plays a supporting role. Although it is difficult for face-to-face teachers to avoid using technology overall, e-teachers depend on it for almost all of their work. This underlines the importance of robust, integrated and well-designed tools that support, rather than hinder, online teachers.

- Online teachers need to cooperate with other members of their institution to a much greater extent in order to obtain the support they need. While it is possible for some innovators to work as "lone rangers", most of the teachers need the support of a host of other people and structures within their institution to teach online. These include curriculum developers, central administrators, computer support staff and librarians.

\section{METHODOLOGY OF RESEARCH AND RESULTS \\ Methodology of Research \\ We are going to do one qualitative study on} two quantitative studies.

According to the department of Special Education in Indiana University, these are the 12 questions addressed to the teachers in order to identify the classroom management profile (style). The steps are simple:

The scoring instructions below are:

1. = Strongly Disagree; 2. = Disagree; $3 .=$ Neutral; 4. = Agree; 5. = Strongly Agree

And at the end of each question we asked the teacher why in order to understand the reason of their answers.

The objective of this study is qualifying the reason of such teachers' classroom management style in order to improve them and to increase students' performance.

The questions are both qualitative and quantitative. We are trying to reach the majority of teachers teaching in professional masters in business. Knowing that we have master only in our three branches, Tripoli, Achrafier and Hadath. We have about 120 teachers teaching in the three branches. And six specializations: marketing, management, finance, accounting, economy and business computer. So our sample for the qualitative study was 47 teachers who answer our qualitative and quantitative questionnaire. We consider the sample is representative when we get answers from 47 teachers from 120 .

The questions are:

1. If a student is disruptive during class, I assign him/her to detention, without further discussion. Why?

2. I don't want to impose any rules on my students. Why? 
3. The classroom must be quiet in order for students to learn. Why?

4. I am concerned about both what my students learn and how they learn. Why?

5. If a student turns in a late homework assignment, it is not my problem. Why?

6. I don't want to reprimand a student because it might hurt his/her feelings. Why?

7. Class preparation isn't worth the effort. Why?

8. I always try to explain the reasons behind my rules and decisions. Why?

9. I will not accept excuses from a student who is tardy. Why?

10. The emotional well-being of my students is more important than classroom control. Why?

11. My students understand that they can interrupt my lecture if they have a relevant question. Why?

12. If a student requests a hall pass, I always honor the request. Why?

The score quiz regarding the first quantitative study is, If we add the responses to statements 1,3 , and 9. This is the score for the authoritarian style.

Statements 4,8 and 11 refer to the authoritative style. Statements 6,10 , and 12 refer to the democratic style. Statements 2, 5, and 7 refer to the laissez-faire style.

The result is the classroom management profile. The score for each management style can range from 3 to 15. A high score indicates a strong preference for that particular style.

As the teacher gain teaching experience, he may find that his preferred style(s) will change. Over time, his profile may become more diverse or more focused. Also, it may be suitable to rely upon a specific style when addressing a particular situation or subject. Perhaps the successful teacher is one who can evaluate a situation and then apply the appropriate style.

To complete the qualitative results and the first quantitative study, a second quantitative questionnaire addressed to 400 students in professional business's masters in order to identify the relationship between teacher management style in and out the classroom and the student performance in the faculty of business at the Lebanese University. The mother population is the same as before: 6 specializations: marketing, management, finance, accounting, economy and business computer.

Liker scale will be used for each question. For each hypothesis we put a question. And at the end of the questionnaire we asked the students' grade to establish a link between teachers' management style perceived by students and their performance.

H1: Teacher management style in class, draw student attention.

Does the classroom teacher management style
H2: Teacher management style out the class, draw student attention.

Does the teacher management style out the classroom attract your attention?

H3: Teacher management style in class let the student to take notes and participate.

Does the teacher management style in the classroom allow you to take notes and participate?

H4: Teacher management style out the class draw student to take notes and participate.

Does the teacher allow you to contact him out the classroom and to take notes and participate to whatsup group discussions and other?

H5: Teacher management style in class allow student to understand better the explanations.

Does the teacher management style in the classroom allow student to understand better the explanations?

H6: Teacher management style out the class, allow student to understand better the explanations.

Does the teacher allow you to contact him out the classroom to ask him questions in order to understand better the explanations?

H7: Teacher management style in class motive student to study.

Does teacher management style in the classroom motive you to study the course?

H8: Teacher management style out the class motive student to study.

Does teacher management style out the classroom motive you to study the course?

H9: Teacher management style in class will let the students cooperate between them in order to succeed.

Does teacher management style in the classroom will push you to cooperate with other students to succeed?

H10: Teacher management style out the class motive student to study and to let the students cooperate between them in order to succeed.

Does teacher management style out the classroom will push you to cooperate with other students to succeed?

H11: Teacher management style in class will help student to succeed in his career.

Does teacher management style in the classroom will help you to succeed in your career? attract your attention? 
H12: Teacher management style out the class will help student to succeed in his career.

Does teacher management style out the classroom will help you to succeed in your career?

My grade average is:

Below 50 over $100=$ Very weak. Between 50 and $59=$ Weak. Between 60 and $69=$ Fairly-well.

Between 70 and $79=$ Good. Between 80 and $89=$ Very Good. Between 90 and $100=$ Excellent.

\section{Results of Teachers' Qualitative Study}

Our sample is 47 teachers. We divided the analysis of teachers' answer to "why" for each question according to two parts. The first one are the answers containing strongly agree and agree. And the second part including answers related to neutral, disagree and strongly disagree.

Question 1: If a student is disruptive during class, I assign him/her to detention, without further discussion. Why?

\section{Strongly agree/agree}

5 teachers agree to assign the student to detention without discussion. Because they prefer to keep the class calm in order to let the students understand their explanations.

\section{Strongly disagree/disagree/neutral}

42 teachers strongly disagree, disagree and are neutral to assign the student to detention without discussion. The majority of answers were to understand the reason behind this behavior. Some answers suggest trying to involve the student in the discussion and other will give him warning before detention.

Question 2: I don't want to impose any rules on my students. Why?

\section{Strongly agree/agree}

3 teachers let students participate in putting rules appropriate for them. 2 teachers said that students have to respect rules.

\section{Strongly disagree/disagree/neutral}

42 teachers few of them strongly disagree, most of them disagree and one is neutral. The all of answers were to have rules in class. Part of them answer that rules are important for maintaining discipline and others for transmitting good level of education.

Question 3: The classroom must be quiet to allow students to learn. Why?

\section{Strongly agree/agree}

31 teachers' answers were like, if the class is quiet, this will strengthen students' listening, understanding and participating. 2 don't give answer.

\section{Strongly disagree/disagree/neutral}

5 teachers are neutral, 3 strongly disagree and 1 disagrees. Teachers give interesting answers like "having controlled fun helps students to enjoy learning". "it depend on the course itself". "Participative learning could not be performed in passive way".

Question 4: I am concerned about both what my students learn and how they learn. Why?

\section{Strongly agree/agree}

32 teachers strongly agree. They said that method will strengthen student's ways of thinking, skills and knowledge.

13 teachers agree that what the students learn and how they learn are important. They mean that the learning methodology is important to let them practice what they did in order to increase their comprehension. And also, it is important to know how student learn to know how to teach them.

\section{Strongly disagree/disagree/neutral \\ 2 teachers disagree. One said that both are important.}

Question 5: If a student turns in a late homework assignment, it is not my problem. Why?

\section{Strongly agree/agree}

2 teachers strongly agree that it is his problem. 9 teachers agree. Most of them said it's his problem he needs to manage his time, and two argue that it could be a special case.

\section{Strongly disagree/disagree/neutral}

36 teachers strongly disagree, disagree and are neutral to understand the reason why the student is late and they try to support him. Very few of them said that don't accept lateness and he has to manage his time.

Question 6: I don't want to reprimand a student because it might hurt his/her feelings. Why?

\section{Strongly agree/agree}

3 teachers agree suggest letting the student participate in putting some rules. 2 teachers said that student have to respect the class rules.

\section{Strongly disagree/disagree/neutral}

42 teachers strongly disagree, disagree and are neutral. Rules will help them to manage the class and to get the student involved.

Question 7: Class preparation isn't worth the effort. Why? 


\section{Strongly agree/agree}

2 teachers strongly agree and agree that class preparation isn't worth the effort.

\section{Strongly disagree/disagree/neutral:}

45 teachers strongly disagree, disagree and are neutral to prepare the class. If no, they will not be able to answer all students' questions. And they can't transfer the latest information to their students.

Question 8: I always try to explain the reasons behind my rules and decisions. Why?

\section{Strongly agree/agree}

33 teachers strongly agree and agree to explain the reasons behind their rules and decisions. They said that students need to understand the rules to apply them.

\section{Strongly disagree/disagree/neutral}

12 teachers strongly disagree, disagree and are neutral to explain the reasons behind his rules and decisions. They said there is no need to explain, students know themselves.

Question 9: I will not accept excuses from a student who is tardy. Why?

\section{Strongly agree/agree}

5 teachers strongly agree, agree to avoid letting it become a habit. But they accept excuses if students have a good reasons.

\section{Strongly disagree/disagree/neutral}

42 teachers strongly disagree, disagree and are neutral. They said "It depends on the excuses".

Question 10: The emotional well-being of my students is more important than classroom control. Why?

\section{Strongly agree/agree}

13 teachers strongly agree and agree. They said "Students are more responsive and learn better in a friendly and responsive ambiance" and "The emotional well being can influence on students learning and efforts".

\section{Strongly disagree/disagree/neutral}

34 teachers strongly disagree, disagree and are neutral. The majority said "it depends on cases". Few of them prefer more control and don't take into consideration the student's emotional well being.

Question 11: My students understand that they can interrupt my lecture if they have a relevant question. Why?

\section{Strongly agree/agree:}

39 teachers strongly agree and agree. Teachers said that interaction is important, "to let students" understand".

\section{Strongly disagree/disagree/neutral:}

7 teachers strongly disagree, disagree and are neutral. The majority allow questions. Two teachers refuse. And oblige students to abide to rules.

Question 12: If a student requests a hall pass, I always honor the request. Why?

\section{Strongly agree/agree}

18 teachers strongly agree and agree to honor the request. Few of them refuse.

\section{Strongly disagree/disagree/neutral}

29 teachers answer the question. Few of them strongly disagree, disagree. They refuse if student's performance is low and allow only the best student.

Most of answers were neutral to honor the request and said it depend to the situations.

\section{Results of Teachers' Quantitative Study}

Table-1: Results of teachers profiles

\begin{tabular}{|l|l|l|l|l|}
\hline Teacher & Authoritarian & Authoritative & Democratic & Laissez-Faire \\
\hline 1 & 9 & 11 & 6 & 4 \\
\hline 2 & 11 & 13 & 9 & 8 \\
\hline 3 & 9 & 13 & 6 & 5 \\
\hline 4 & 8 & 12 & 11 & 6 \\
\hline 5 & 9 & 15 & 12 & 6 \\
\hline 6 & 5 & 14 & 10 & 11 \\
\hline 7 & 8 & 10 & 12 & 6 \\
\hline 8 & 8 & 12 & 11 & 6 \\
\hline 9 & 9 & 12 & 8 & 6 \\
\hline 10 & 8 & 12 & 11 & 7 \\
\hline 11 & 9 & 11 & 12 & 6 \\
\hline 12 & 7 & 14 & 9 & 5 \\
\hline 13 & 7 & 15 & 12 & 6 \\
\hline 14 & 9 & 8 & 10 & 5 \\
\hline 15 & 6 & 14 & 10 & 6 \\
\hline
\end{tabular}




\begin{tabular}{|l|l|l|l|l|}
\hline 16 & 7 & 12 & 11 & 6 \\
\hline 17 & 5 & 15 & 9 & 4 \\
\hline 18 & 8 & 13 & 10 & 5 \\
\hline 19 & 8 & 13 & 9 & 7 \\
\hline 20 & 6 & 12 & 13 & 6 \\
\hline 21 & 8 & 12 & 8 & 6 \\
\hline 22 & 9 & 11 & 12 & 5 \\
\hline 23 & 9 & 13 & 8 & 3 \\
\hline 24 & 6 & 15 & 7 & 6 \\
\hline 25 & 7 & 12 & 7 & 6 \\
\hline 26 & 11 & 13 & 10 & 7 \\
\hline 27 & 8 & 15 & 7 & 6 \\
\hline 28 & 10 & 12 & 11 & 8 \\
\hline 29 & 11 & 12 & 8 & 6 \\
\hline 30 & 11 & 11 & 9 & 7 \\
\hline 31 & 6 & 13 & 8 & 6 \\
\hline 32 & 8 & 11 & 10 & 5 \\
\hline 33 & 8 & 13 & 12 & 10 \\
\hline 34 & 9 & 10 & 10 & 5 \\
\hline 35 & 3 & 3 & 3 & 3 \\
\hline 36 & 8 & 15 & 7 & 6 \\
\hline 37 & 12 & 14 & 13 & 9 \\
\hline 38 & 10 & 12 & 9 & 8 \\
\hline 39 & 10 & 10 & 8 & 7 \\
\hline 40 & 5 & 10 & 7 & 6 \\
\hline 41 & 6 & 12 & 7 & 4 \\
\hline 42 & 7 & 13 & 12 & 6 \\
\hline 43 & 9 & 13 & 9 & 5 \\
\hline 44 & 8 & 14 & 7 & 6 \\
\hline 45 & 9 & 13 & 7 & 4 \\
\hline 46 & 13 & 13 & 7 & 7 \\
\hline 47 & 11 & 13 & 10 & 8 \\
\hline & & & & \\
\hline & 9 & 9 & 9 \\
\hline
\end{tabular}

When analyzing numbers, we consider 15 is the maximum answer a teacher can give us. And the average of 15 is 7,5. So 8 mean above the average and indicate that the teacher has a favorable answer toward the way the teacher manage his class (Authoritarian, authoritative, democratic or laissez-faire).

So according to the results we get 33 authoritarian teachers that represent about $70 \%$ of teachers; 46 are authoritative $(97,8 \%), 35$ are democratic $(74,4 \%)$ and 7 are laissez-faire.

But as we notice we have teachers that have many profiles at the same time. And this mean that some teachers don't only belongs to one profile. So we try to know the number of teachers that have only one profile and consequently we deduce from 46 authoritative teachers authoritarian and laissez-faire. And we leave the democratic teachers within the authoritative teachers, so we get 9 teachers which mean $19,14 \%$ are pure authoritative mainly and then democratic in the Lebanese university and as a result, 31 are authoritarian teachers (47 total number of the sample -9 authoritative and democratic -7 laissezfaire).
By conclusion $65,95 \%$ (31) of teachers teaching masters in the Lebanese university are authoritarian. $14,89 \%$ (7) laissez-faire. $19,14 \%$ (9) are authoritative and democratic.

\section{Results of students' quantitative study Descriptive results}

Reliability statistics is 0.847 for Cronbach's Alpha.

Question 1: Does the classroom teacher management style attract your attention?

Number of responses: 428 responses.

The answers where as follow: strongly agree $48.4 \%$, agree $38.6 \%$, neutral $7 \%$, $4 \%$ disagree, $2 \%$ strongly disagree. The mean results is 4.28 which signify that teacher management style attract students' attention.

Question 2: Does the teacher management style out the classroom attract your attention?

Number of responses: 427 responses.

The answers where as follow: strongly agree $17.8 \%$, agree $45.4 \%$, neutral $27.4 \%$, $7 \%$ disagree, $2.4 \%$ strongly disagree. The mean is 3.7 which signify that mainly teacher attract students' attention outside the class by answer to their questions. 
Question 3: Does the teacher management style in the classroom allow you to take notes and participate?

Number of responses: 426 responses.

The answers where as follow: strongly agree $37.3 \%$, agree $50 \%$, neutral $8.3 \%$, disagree $2.4 \%$, strongly disagree $2 \%$. The mean is 4.2 which signify that the teacher allow students to take notes.

Question 4: Does the teacher allow you to contact him out the classroom and to take notes and participate to whatsup group discussions and other?

Number of responses: 427 responses.

The answers where as follow: strongly agree 19\%, agree $40.3 \%$, neutral $25.8 \%$, disagree $11.7 \%$, strongly disagree $3.2 \%$. The mean is 3.58 which signify that mainly teachers allow students to contact them out the classroom and to take notes and to participate to whatsup group discussion.

Question 5: Does the teacher management style in the classroom allow student to understand better the explanations?

Number of responses: 425 responses.

The answers where as follow: strongly agree $38.4 \%$, agree $49.6 \%$, neutral $7.5 \%$, disagree $2.5 \%$, strongly disagree $2 \%$. The mean is 4.2 which indicate that the whole majority of teachers make students understand better the explanations.

Question 6: Does the teacher allow you to contact him out the classroom to ask him questions in order to understand better the explanations?

Number of responses: 425 responses.

The answers where as follow: strongly agree $15.3 \%$, agree $41.9 \%$, neutral $27.5 \%$, disagree $12 \%$, strongly disagree $3.3 \%$. The mean is 3.5 which explain that a small majority of teachers allow students to contact them out the classroom in order to ask them questions to let them understand better.

Question 7: Does teacher management style in the classroom motive you to study the course?

Number of responses: 425 responses.

The answers where as follow: strongly agree $44.2 \%$, agree $41.9 \%$, neutral $7.9 \%$, disagree $4 \%$ strongly disagree $2 \%$. The mean is 4.2 which signify that the majority of teachers motive students to study.

Question 8: Does teacher management style out the classroom motive you to study the course? Number of responses: 421 responses.
The answers where as follow: strongly agree $12.8 \%$, agree $36.3 \%$, neutral $31.4 \%$, disagree $15.4 \%$, strongly disagree $4.1 \%$. The mean is 3.3 which indicate that less than a half of teachers' (strongly agree $12.8 \%$, agree $36.3 \%$ ) motive students out the class.

Question 9: Does teacher management style in the classroom will push you to cooperate with other students to succeed?

Number of responses: 425 responses.

The answers where as follow: strongly agree $19.3 \%$, agree $55.8 \%$, neutral $16.7 \%$, disagree $5.5 \%$, strongly disagree $2.7 \%$. The mean is 3.8 which indicate that the majority of teachers push students to cooperate in class in order to succeed.

Question 10: Does teacher management style out the classroom will push you to cooperate with other students to succeed?

Number of responses: 424 responses.

The answers where as follow: strongly agree $11,1 \%$, agree $42,2 \%$, neutral $30,2 \%$, disagree $12,5 \%$, strongly disagree $4 \%$. The mean is 3.4 which indicate that small majority of teachers push students to cooperate outside the class in order to succeed.

Question 11: Does teacher management style in the classroom will help you to succeed in your career?

Number of responses: 423 responses.

The answers where as follow: strongly agree $16.1 \%$, agree $43.7 \%$, neutral $23.6 \%$, disagree $12.8 \%$, strongly disagree $3.8 \%$. The mean is 3.5 which indicate that a small majority help students to succeed in their career.

Question 12: Does teacher management style out the classroom will help you to succeed in your career?

Number of responses: 424 responses.

The answers where as follow: strongly agree $11.8 \%$, agree $35.1 \%$, neutral $31.4 \%$, disagree $17.2 \%$, strongly disagree $4.5 \%$. The mean is 3.3 which indicate that less of half teachers help students out the class to succeed in their career.

Question 13: The average students' grade is: Number of responses: 426 responses.

Less than $50=1 \%$. Between 50 to $59=7,4 \%$. Between 60 to $69=20,2 \%$. Between 70 to $79=41,3 \%$. Between 80 to $89=26,1 \%$. Between 90 to $100=4 \%$.

The mean is 78.2 over 100 . This indicates the majority of our master students $(71.4 \%)$ are above 70 over 100 . 


\section{Correlations Results}

Table-2: Correlations between hypotheses

\begin{tabular}{|l|l|l|l|l|l|l|l|l|l|l|l|l|}
\hline & Q1 & Q2 & Q3 & Q4 & Q5 & Q6 & Q7 & Q8 & Q9 & Q10 & Q11 & Q12 \\
\hline Q1 & & & 0.52 & & 0.6 & & 0.5 & & & & & \\
\hline Q2 & & & & & & & & & & & & \\
\hline Q3 & & & & & 0.6 & & & & & & & \\
\hline Q4 & & & & & & 0.58 & & & & & & \\
\hline Q5 & & & & & & & 0.53 & & & & & \\
\hline Q6 & & & & & & & & & & & & \\
\hline Q7 & & & & & & & & & & & & \\
\hline Q8 & & & & & & & & & & 0.56 & & 0.54 \\
\hline Q9 & & & & & & & & & & 0.53 & & \\
\hline Q10 & & & & & & & & & & & & \\
\hline Q11 & & & & & & & & & & & & 0.68 \\
\hline Q12 & & & & & & & & & & & & \\
\hline
\end{tabular}

These are the questions that there are correlations between them at show in the table above:

1. Teacher attracts your attention in class.

2. Teacher in the classroom allows you to take notes and participate.

3. Teacher allows you to contact him out the classroom and to take notes and participate to whatsup group discussions and other.

4. Teacher in the classroom allow student to understand better the explanations.

5. Teacher allows you to contact him out the classroom to ask him questions in order to understand better the explanations.

6. Teacher in the classroom motives you to study the course.

7. Teacher out the classroom motives you to study the course.

8. Teacher in the classroom will push you to cooperate with other students to succeed.

9. Teacher out the classroom will push you to cooperate with other students to succeed.

10. Teacher in the classroom will help you to succeed in your career.

11. Teacher out the classroom will help you to succeed in your career.

\section{RECOMMENDATIONS AND CONCLUSIONS MANAGERIAL RECOMMENDATIONS}

There are a need for a follow-up that should be done from the head of the department in order to reduce the number of laissez-faire teachers $(14,89 \%)$ and in particularly the authoritarian one $(65,95 \%)$. at the same time there is an urgent need for training with the intention of educating teachers to become authoritative and particularly transformational teachers.

The content of this training should contain factors improving management style and understanding how to help student to perform in their studies. These advices and instructions are as follow:

1) A student said: To increase my knowledge, I don't have the opportunity to travel, to have summer camp, home computers, music, arts and sports lessons...
And also, some time, students lack of belonging to community, neighborhood or school, they don't have adults to advice them and to help them to face problems in their life, in and out the school. As a results, hope for them is difficult to attain. And as a consequence they have a low level of confidence and self respect. And some time they have barriers to study at home. So, teacher should understand and help student.

2) Teacher should motive students.

3) Teachers are peddlers of hope.

4) Allow students to ask the teacher questions in order to understand.

5) Interaction with students allows them to get high achievement (comprehension and results). So, the student can interrupt teacher's lecture if he has a relevant question. But if he asks for a hall pass, the answer will depend to the situation.

6) Teacher has to accept private interactions with his student after the class (out the class; phone call; via whatsup; email...).

7) Student expectations vary according to the course. But clear rules reduce students' anxiety.

8) To understand the courses explanation some students prefer: Seeing, watching, viewing and drawing. Other prefers to listen and to speak to understand and other prefers demonstration, and direct involvement.

9) To help student to apply time management because some student prefer to study before the exam.

10) If students receives praise and encouragement frequently this will support them.

11) It is important that teacher express interest and affection to the student.

12) Teacher has to respects the strengths and weaknesses of his students and turns them into positive expectations.

13) Teacher should maintain a healthy sense of humor. Students want to know that teachers are human too!

14) Teacher doesn't have to hold grudge towards student.

15) Practicing case study after each chapter is important to understand. 
16) To see a movie, visit a factory or other materials related to the courses are a plus to understand the chapter.

17) Not all teachers ask project. Project done by student applied to the market is a plus to understand more the course.

18) Very indulgent teacher can't control the class.

19) Not all students did the project seriously. And the result of an indulgent teacher is a student how will lack of competence. So, the teacher doesn't have to accept that rules will be transgressed.

20) Rules and quiet classes are important and maintain discipline and allow transmitting good level of education.

21) Participative learning and having controlled fun helps students to enjoy learning.

22) Lot of example allows the student to understand more the chapter.

23) Information given by the teacher should be up-todate.

24) Teacher should be creative.

25) Teacher should prepare his class to let him be able to answer students' questions and to transfer them the latest information.

26) Teacher adapts creative solutions to preserve students' performance.

27) Teacher adapts teaching method according to class situation.
28) Teacher goes beyond the syllabus to let the student understand. He works collectively and individually with them.

29) Teacher share class room decision with students.

30) Rules are discussed with students, but teacher has the final word to affect positively student behavior and academic achievement.

31) Rules help the teacher to manage the class and to get the student involved.

32) Giving choices to student allow him to better understand and to develop his skills.

33) Because of the positive social climate and active participation of students in the teaching and learning process, the classroom becomes a stimulating and safe learning environment. The student will learn better in a friendly and responsive ambiance. So that mean the emotional well-being of the student is important.

34) Teacher always choose the right way to change a negative student behavior into positive one. Avoid punishing student for a small mistake.

35) If a student turns in a late homework assignment, teacher try to understand the reason why he is late and they have to try to support him to learn how to manage his time.

36) Student should feel always that the teacher has the ability to lead the class.

37) If a student disruptive during class, try to understand the reason. If the reason is harmful punish him.

\section{THEORICAL RECOMMENDATIONS}

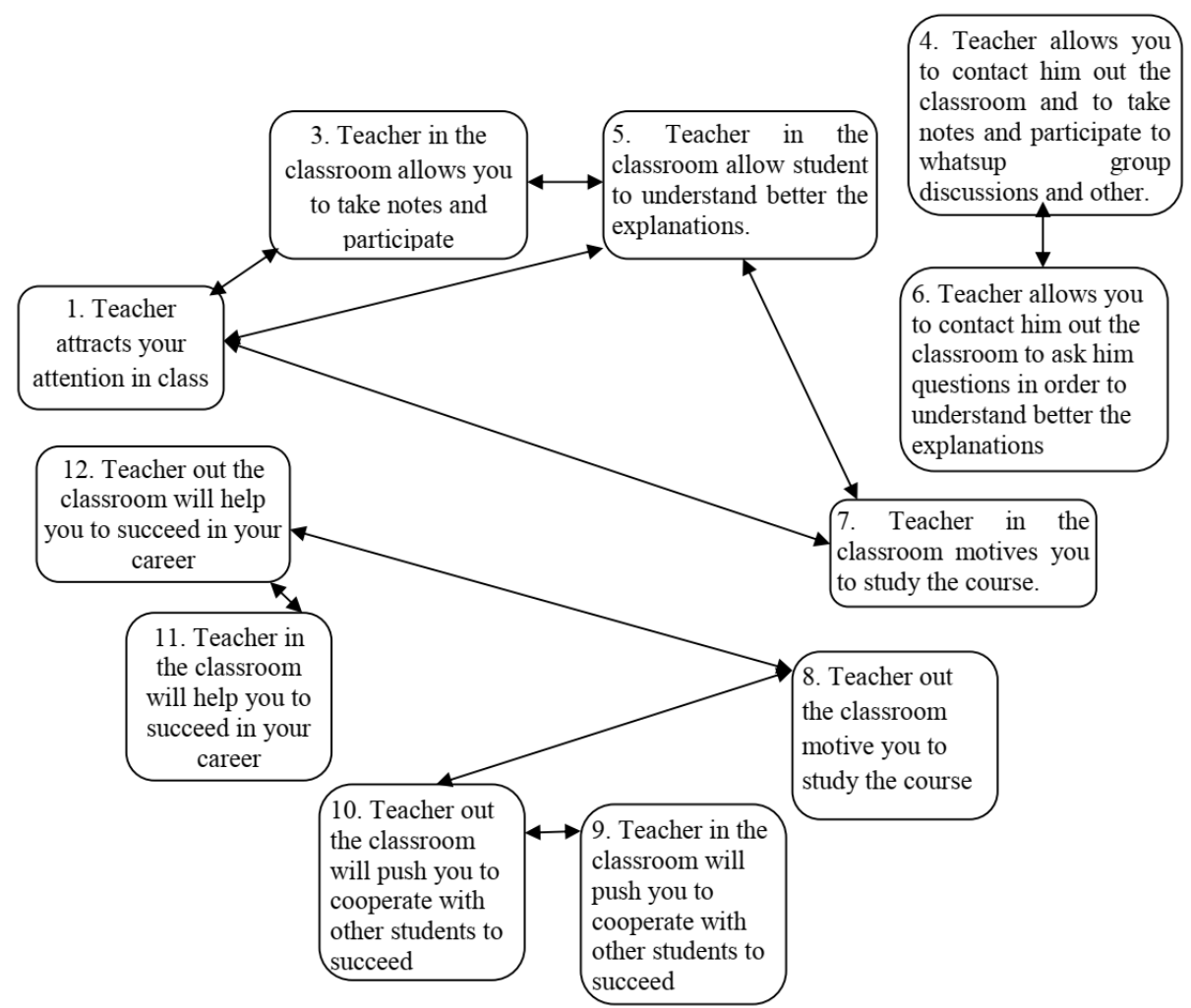

Fig-4: Correlations results between hypotheses Done by Antoine TANNOUS 
Based on Figure-4 we notice a correlation between these four hypotheses:

1. Teacher attracts your attention in class.

2. Teacher in the classroom allows you to take notes and participate.

3. Teacher in the classroom allow student to understand better the explanations.

4. Teacher in the classroom motives you to study the course.

This means that students are well influenced by the most important factors that allow them to perform. These factors are attention, taking notes and participating in class, allowing student to ask questions to better understand explanations and finally the motivation done by teachers.

Also, we notice an interesting correlation between the two hypotheses which may allow students to perform.

1. Teacher allows you to contact him out the classroom and to take notes and participate to whatsup group discussions and other.

2. Teacher allows you to contact him out the classroom to ask him questions in order to understand better the explanations.

Furthermore, we notice correlation between these five hypotheses as figure 4. As well, these correlations will allow student to perform.

1. Teacher out the classroom motives you to study the course.
2. Teacher in the classroom will push you to cooperate with other students to succeed.

3. Teacher out the classroom will push you to cooperate with other students to succeed.

4. Teacher in the classroom will help you to succeed in your career.

5. Teacher out the classroom will help you to succeed in your career.

We notice also that there are no correlations between students' grade and the 12 hypotheses. That means that as usual students at the Lebanese University count on their own effort to succeed in classes, despite teachers' management styles. But it doesn't mean that teachers' management style doesn't influence students if they do enough effort for that.

To conclude, correlation between these set of variable (12 hypotheses) are moderate (0.5) and sometime non-existent as we notice in the Table-2. So teachers should work more, in order to increase this correlation, to benefit more students. And transform their management style in and out the class from authoritarian to authoritative and even transformational style.

\section{CONCLUSION AND LIMITATIONS}

Hypotheses that they have triple $\mathrm{X}$ have a high validation, double $X$ have middle validation and one $X$ have low validation.

Table-3: Mean for each hypothesis

\begin{tabular}{|l|l|l|}
\hline H1: Does the classroom teacher management style attract your attention? & Mean & Validate \\
\hline H2: Does the teacher management style out the classroom attract your attention? & 4.279 & XXX \\
\hline H3: Does the teacher management style in the classroom allow you to take notes and participate? & 3.702 & $\mathrm{XX}$ \\
\hline H4: Does the teacher allow you to contact him out the classroom and to take notes and participate to & 3.579 \\
whatsup group discussions and other? & $\mathrm{X}$ \\
\hline $\begin{array}{l}\text { H5: Does the teacher management style in the classroom allow student to understand better the } \\
\text { explanations? }\end{array}$ & 4.218 & $\mathrm{XXX}$ \\
\hline $\begin{array}{l}\text { H6: Does the teacher allow you to contact him out the classroom to ask him questions in order to } \\
\text { understand better the explanations? }\end{array}$ & 3.531 & $\mathrm{X}$ \\
\hline H7: Does teacher management style in the classroom motive you to study the course? & 4.200 & $\mathrm{XXX}$ \\
\hline H8: Does teacher management style out the classroom motive you to study the course? & $\mathrm{XXX}$ \\
\hline $\begin{array}{l}\text { H9: Does teacher management style in the classroom will push you to cooperate with other students to } \\
\text { succeed? }\end{array}$ & 3.831 & $\mathrm{XX}$ \\
\hline $\begin{array}{l}\text { H10: Does teacher management style out the classroom will push you to cooperate with other students to } \\
\text { succeed? }\end{array}$ & 3.438 & $\mathrm{X}$ \\
\hline H11: Does teacher management style in the classroom will help you to succeed in your career? \\
\hline H12: Does teacher management style out the classroom will help you to succeed in your career? \\
\hline
\end{tabular}

Regarding hypotheses with one X: Teachers should have important improvement in $\mathrm{H} 4, \mathrm{H} 6, \mathrm{H} 8, \mathrm{H} 10, \mathrm{H} 11$ and $\mathrm{H} 12$.

H4. Teachers should allow students to contact them out the classroom and to take notes and participate to whatsup group discussions and other.
H6. Teachers should allow students to contact them out the classroom to ask them questions in order to understand better the explanations. H8. Teachers should motive students out the classroom to study the course.

H10. Teachers out the classroom should push students to cooperate with other students to succeed. 
H11. Teachers in the classroom should help students to succeed in their career.

H12. Teacher out the classroom should help students to succeed in their career.

Regarding hypotheses with double X: Teachers should have improvement in $\mathrm{H} 2$ and $\mathrm{H} 9$.

H2. Teacher management style out the classroom should attract students' attention.

H9. Teacher management style in the classroom should push students to cooperate with other students in order to succeed.

Limitation is related to the studies that have been done only on teachers and students teaching master degree at the faculty of business in the Lebanese University.

As a further research I recommend questions complementariness' to our topic as follow:

What style of management will you introduce once you start teaching? Which style best fits your personality? Do you feel comfortable with this style? How did you work to make changes if you did not like what you see?

\section{REFERENCES}

1. Bycio P, Hackett RD, Allen JS. Further assessments of Bass's (1985) conceptualization of transactional and transformational leadership. Journal of applied psychology. 1995 Aug;80(4):468.

2. Bass BM, Avolio BJ. Potential biases in leadership measures: How prototypes, leniency, and general satisfaction relate to ratings and rankings of transformational and transactional leadership constructs. Educational and psychological measurement. 1989 Sep;49(3):509-27.

3. Hater JJ, Bass BM. Superiors' evaluations and subordinates' perceptions of transformational and transactional leadership. Journal of Applied psychology. 1988 Nov;73(4):695.

4. Den Hartog DN, Van Muijen JJ, Koopman PL. Transactional versus transformational leadership: An analysis of the MLQ. Journal of occupational and organizational psychology. 1997 Mar;70(1):19-34.

5. Hinkin TR, Tracey JB. An analysis of variance approach to content validation. Organizational Research Methods. 1999 Apr;2(2):175-86.

6. Okoroji L, Anyanwu O, Ukpere W. Impact of leadership styles on teaching and learning process in Imo state. Mediterranean journal of social sciences. Vol 5 No4. March. MCSER Publishing, Rome-Italy. 2014; 180-193.

7. Eagly AH, Johnson BT. Gender and leadership style: A meta-analysis. Psychological Bulletin, 1990;108:233-256.

8. Rosener J. Ways women lead. Harvard Business Review, 1990; 68: 119-125.
9. Pounder. The classroom leadership styles of Hong Kong University teachers: A case study of teachers in a business school. PHD thesis. University of Leicester. 2004.

10. Ojode LA, Walumbwa FO, Kuchinke P. Developing Human Capital For the Evolving Work Environment: Transactional and Transformational Leadership Within Instructional Setting, Midwest Academy of Management. Annual Conference at Lincoln, Nebraska, April 16th-17th. 1999.

11. Walumbwa FO, Ojode LA. Gender stereotype and instructors' leadership behavior: Transformational and transactional leadership. InMidwest Academy of Management Annual Conference at Chicago, March 30th-April 1st 2000 Mar. Walumbwa FO, Ojode LA. Gender stereotype and instructors' leadership behavior: Transformational and transactional leadership. InMidwest Academy of Management Annual Conference at Chicago, March 30th-April 1st 2000 Mar.

12. Maeroff GI. Altered destinies: Making life better for children in need. Phi Delta Kappan, 1998, February; 79, 424-432.

13. Jones F. Tools for teaching. Santa Cruz, CA: Fredric H. Jones \& Associates. 2000.

14. Durodola S. Teachers' Management styles: two case studies from a school in the Penetown area of the University Kwazulu-Natal. Pinetown, Durban. 2009.

15. Brown M, Owusu AA. Influence of Head teachers' Management Styles on Teacher Motivation in Selected Senior High Schools in the Sunyani Municipality of Ghana. International Journal of Learning, Teaching and Educational Research. 2014 Apr 30;4(1):61-75.

16. Parveen R. The Relationship between Classroom Management Styles and Coping Strategies with Stress. International journal of graduate research and review, 2018; 4(2): 36-43.

17. Moore GE. Cramming more components onto integrated circuits. Proceedings of the IEEE. 1998 Jan;86(1):82-5.

18. Sultan S, Shafi M. Impact of Perceived Teachers' Competence on Students' Performance: Evidence for Mediating/Moderating Role of Class Environment. Journal on educational psychology. 2014;8(1):10-8.

19. Emmer ET. Classroom management and discipline. In Richardson-Koehler V, \& Berliner DC. (Eds.), Educators' handbook: A research perspective (pp. 233- 258). White Plains, NY: Longman. 1987.

20. Elliot ES, McGregor HA, Gable SL. Achievement goals, study strategies, and exam performance: A mediational analysis. Journal of Educational Psychology, 1999;91:549-563.

21. Hsu PP. The Relationship among Teacher characteristics. Teacher-Student Interaction and 
Students Academic Achievement. Bulletin of Educational Psychology, 1983:16:99-114.

22. Muzenda A. Lecturers' competences and students' academic performance. International Journal of Humanities and Social Science Invention. 2013 Jan;3(1):6-13.

23. Prasetio AP, Azis E, Fadhilah DD, Fauziah AF. Lecturers' professional competency and students' academic performance in indonesia higher education. International Journal of Human Resource Studies. 2017;7(1):86-93.

24. Sun X. A Commentary on the Innovation of China's Lifelong Education Theory. International Journal of Continuing Education and Lifelong Learning. 2011 May;3(2):1.
25. Rennie F, Jóhannesdóttir S, Kristinsdottir S. Rethinking sustainable education systems in Iceland: The Net-University project. The International Review of Research in Open and Distributed Learning. 2011 May 13;12(4):88-105.

26. Cowan JE. Strategies for developing a community of practice: Nine years of lessons learned in a hybrid technology education master's program. TechTrends. 2012 Jan 1;56(1):12-8.

27. Bennett S, Lockyer L. Becoming an online teacher: Adapting to a changed environment for teaching and learning in higher education. Educational Media International. 2004 Sep 1;41(3):231-48. 